\title{
A Study on Defects and Causes in Current Financial Reports
}

\author{
Hua Fang \\ School of Management, Xi'an University of Science and Technology \\ Xi'an 710054, China \\ Tel: 86-29-8160-6234Ｅ-mail: nancysunyf@163.com
}

\begin{abstract}
The traditional pattern of financial reports, an outcome of social economic development, has displayed its defects in the new economic environment. Unable to adapt itself to the needs of intellectual economy, this pattern can not reveal some non-financial information, prospective information, uncertain information as well as large intangible assets of some potential enterprises, hence failing to satisfy their users' demands for prediction. This article analyzes the defects and causes of current financial reports in the aspects of information demands and supplies.
\end{abstract}

Keywords: Financial reports, Information demands and supplies, Variance analysis

As a special commodity, accounting information involves the supplier and the demander. Just due to the interaction between the two, some of the accounting information is revealed. In order to test the consistency between the supplies and demands of the revealed accounting information about China's quoted companies, we conducted an investigation on investors' demands for accounting information as well as the accounting information disclosure of quoted companies.

\section{Defects of Current Financial Report System}

The survey on investors' demands shows: (1) $42 \%$ of investors are in a bad need of future information while only $10 \%$ of them are interested in historical information; generally, investors have greater demands for future information than historical one. (2) $22 \%$ of investors need financial information very much while $23 \%$ of them require non-financial information; generally, investors need not only financial information but non-financial one. (3) investors have greater demands for regular and temporary reports and their demands for financial reports become less with the shortening of financial report period.

According to the survey on the supplies of quoted companies, (1) the evaluation of estimate for future information and non-financial information is much greater than that for historical information and non-financial one; quoted companies disclose more about historical and financial information than future and non-financial one. (2) quoted companies have high disclosure degree in their regular and temporary reports and this degree tends to be lower with the shortening of the regular report period.

To sum up, the current financial report system is far from satisfying the information users' needs. In addition to the above asymmetry between supplies and demands, some other problems lying in the present financial reports include:

1) Emphasizing the history of enterprises' operation while neglecting their prospective development. In terms of measurement, financial reports mainly focus on historical cost to provide enterprises with the historical financial information, that is, "to provide the historical images of enterprises' economic activities and results based on their past transactions with money as the main measurement unit". Due to its basis on the past transactions, financial information, especially the information embodied in financial reports, is mainly based on the past. In spite of the importance of historical information in predicting the future, the users are unable to make their decisions only with it. Prospective information, which seems increasingly important in the decision-making process, cannot be reflected in the current financial reports.

2) Emphasizing the confirmation, measurement and report of enterprises' tangible assets and financial assets while neglecting that of their intangible assets and intellectual assets. As required in financial reports, all listed assets are expected to be definable, measurable, relevant and reliable. Compared with tangible assets, intangible ones have uncertain future economic profit and are more difficult to be measured as well as dominated by enterprises. Therefore, most intangible assets, such as self-created reputation and human resources, are thrown out of financial reports due to their failure to meet the strict standards. 
3) Emphasizing the disclosure of financial information while neglecting that of non-financial one. Traditional financial reports are mainly intended to offer financial information. As financial information only involves a short term, it is unable to show the dynamic process of an enterprise's operation and production, hence failing to explain its long-term value. Good financial indexes don't necessarily reflect a healthy operation and a long-term development because some enterprises may sacrifice their long-term value for maximized short-term financial achievements. Not only financial information but non-financial one as well as non-financial achievement indexes should be relied on to reflect the long-term value of an enterprise properly. Since the information listed in financial reports is about an enterprise's operation achievements which result from the interaction among many factors, current financial reports only inform their users of the operation of an enterprise instead of a variety of elements that make it, especially some non-financial elements not listed in them, such as technological innovation, human resource management, corporate reputation, energy sources and sales channels and so on. Unable to be described in monetary form, these factors cannot be listed in financial reports.

4) Emphasizing the total sum reflected in financial situation and achievements while neglecting some potential risks and uncertainty in operation. As pointed out by FASB in No.1 Concept Statements, financial reports aim at helping present or potential investors, creditors and other users to assess the actually earned sum, time distribution and uncertainty in sales, payment or loans. Therefore, it is one part of financial reports to disclose the risks and uncertainty enterprises are facing. However, our current financial reports, focusing on the disclosure of some possible market risks and credit risks for relevant financial instruments while lacking in that of potential operation and financial risks facing enterprises, fail to convey the overall risks to information users. As for the prospective and uncertain information which is most important, some deep-rooted principles, such as the historical cost principle, the realization principle and the reliability principle, are kept out of financial reports.

In addition, with the arrival of the intellectual economy era which leads to the constant shortening of product life circle as well as the rise of derived financial instruments, enterprises' production and operation are made uncertain. In this case, if we use the traditional financial reports, which mainly employ regular reports to reflect some relevant information, the quality and usefulness of financial information will be influenced.

\section{An Analysis on the Above Problems}

1) Analyzing the restrictions of the object itself. Financial reports have limits because of the gap between financial information demands and it in quantity and quality. Reasons for this gap include: first, the application of accrual basis enables information suppliers with an opportunity to explain enterprises' earnings management with their reasonable subjective judgment. Actually, the present disorder between the uncertainty and certainty of financial report items is caused by the application of accrual basis, which leads to estimation and judgment when processing financial information, such as the withdrawal of bad debt provisions, the depreciation length of fixed assets, the confirmation of residual value and the cognizance of intangible assets' economy life span. But the current financial accounting pattern conceals this feature by listing some very definite numbers, which greatly influences the users' understanding and employment of the given financial accounting information. They can only verify these numbers in different ways or even decompose these numbers one by one with great efforts, and finally recombine them according to their judgment. Second, according to the definition of financial elements, financial reports or statements are mainly summary statements with historical accounting records. As required in "the usefulness for decision making", financial elements should include the transactions and matters involved now and in the future. However, this is not the fact. In reality, financial report information comes from the accounting information created in the framework of accounting hypotheses and principles, the employment of which will result in the gap between the given information and the demanded one as well as the improvement of information standardization.

2) The accounting information demanders' understanding capacity is an important factor for information utility. For those users lacking in certain accounting knowledge, the usefulness of the information listed in financial report analysis will be influenced due to their unclear demands or their sequacious use of information.

3) Some demands of accounting information users may be unreasonable or hard for enterprises to offer. With the increasing types of derived financial instruments, these instruments may bring about dramatic changes in enterprises' future financial conditions and profit-earning abilities. With their risks not disclosed, these instruments will cause accounting report users' decision-making errors in investment and credit. That is because accounting information isn't the whole information of an enterprise. As for enterprises, some accounting information is their secret and cannot be disclosed freely. Otherwise, misunderstandings will rise among investors.

To sum up, the current financial reports, focused on financial resources and conditions, mainly put importance on disclosing enterprises' past financial resources and present financial conditions while neglecting the disclosure of their future financial potentials and financial core abilities. Actually, users need the latter information as well as the former one. However, our present financial report system, which is based on financial resource information and emphasizes financial condition, only discloses enterprises' financial abilities indirectly (including their profit-earning ability, 
debt-paying ability, operation ability and growing ability). In a complex and changeable environment, both financial resources and conditions tend to change. Therefore, our current financial reports are doing not enough in prediction and foresight.

\section{Suggestions for Improving Current Financial Reports}

Current accounting reports are stuck in trouble: on one hand, investors blame them for reduced relevance of the information they include; on the other hand, due to the failure to include a great deal of information caused by our present confirmation and measurement technology and basic characteristics of financial accounting, the information can only be disclosed off sheet, which results in the sharp increase of off-sheet information. Even if with this off-sheet disclosure, a considerable part of valuable items cannot be disclosed in the present financial report system. Therefore, these reports should be enriched and made more flexible to improve the use value of accounting information.

\subsection{Predictive Information}

Predictive information refers to the prediction about enterprises' future financial conditions, operation achievements and cash flow with scientific prediction methods based on their current conditions and taking all kinds of certain or uncertain elements in the future into consideration. With the development and perfection of capital market, present or potential investors have greater demands for the information about an enterprise' future operation. As for information users, this seems particularly important for them to make decisions. Predictive information is like a bond connecting the past and the future, which helps present and potential investors, creditors and other users to evaluate the future sum, time distribution and uncertainty of cash flow.

\subsection{Non-financial Information}

Not only financial but non-financial information play a significant role in the decision-making process. Some information, such as market shares, customer satisfaction, $R \& D$ of new products and so on, helps its users to learn about the whole operation process and prospects.

\subsection{Analysis on Financial and Non-financial Information}

With scientific and careful analyses conducted by enterprise administrators on financial and non-financial information, its users will not feel hard to understand or even misunderstand the given information due to their lack of professional knowledge.

\subsection{Information on Corporate Environment}

With the development of the whole society, there is a closer relationship between enterprises and environment. The effects of environment on an enterprise's survival and development include both its direct influences and the influences of some social reasons caused by environment on an enterprise.

\section{References}

Li, Zhaoxia. (2008). On the Disclosure Range of Financial Accounting Reports. Economy Forum. 03. pp.137-138.

Tu, Hongwei. (2008). An Exploration into Enterprises' Financial Accounting Reports. Market Modernization, 30.pp. 312-314.

Zhang, Mingyan. (2008). Some Suggestions for Improving the Delivery of Financial Accounting Reports. 07. pp.22-23. 